\title{
Identification of Agronomic Traits of Centella asiatica (L.) Urban. Naturally Grown at Regions With Different Altitudes
}

\author{
Entis Sutisna Halimi \\ Department of Agroecotechnology, Faculty of Agriculture, University of Sriwijaya, Palembang 30662 \\ Diterima 26-08-2010 Disetujui 02-03-2011
}

\begin{abstract}
The Centella asiatica is an important herbal plant in Indonesia. The research was done to describe several agronomic traits that related to yield of the plants grown at regions with different altitudes. The research was carried out at three different regions of highland, midland, and lowerland, each at $>500 \mathrm{~m}, 250-500 \mathrm{~m}$, and $<250 \mathrm{~m}$ above sea level. The research location was Pagar Alam, Musi Rawas, and Ogan Ilir, respectively. Research indicated that the agronomic traits of the plants grown at highland, midland, and lowerland, regions were about the same for general appearance of leaf shape and flower color. The leaf size, number and length of stolone, number of rossets, length of rhizomes, and number of flower were varied depending on the region. The plants grown at highland and midland region tend to have larger leaf size, shorter petiole and stolone, more number of rossets and stolone, longer rhizomes, and more number of flowers per plant, compared to the plants of lowerland region. This could be indication that Centella asiatica plants grown on midland, and highland were more productive than plants of lowerland region.
\end{abstract}

Keywords: agronomic-trait, Centella-asiatica, herbal, Latitude

\section{INTRODUCTION}

Indonesia is well known as a rich country of having abundant species of plants. Many of them $(>1.300$ species) were considered as medicine plant including Centella asiatica (L.) Urban. (Sangat et al., 2000). Winarto and Surbakti (2002), stated that distribution area of the Centella asiatica plants cover large area in tropical as well as in the subtropical region including Southeast Asia, India, Pakistan, China, the Middle East, Europe, and Australia. In these area the plants were mainly used for medications and culinary. In China, they called the plants as a miracle elixir of life (Khare, 2003). As the increase in science and technology, the use of Centella asiatica plant becomes more various not only for medication and culinary, but also for cosmetic purposes (Lasmadiwati et al., 2004).

With respect to the distribution area in Indonesia, the Centella asiatica plant has many local names. In many area in Sumatera the plant was called as Daun Kaki Kuda, Daun Aga, and Pegagan. In Java, Madura, and Bali the plant was called as Gowang, Dulang Sontak, Antanan, Calingan Rambat, Kos Tesan, and Taidah. In Celebes, the plant was called as Daun Wisuwisu, Eipubalo, Kolotidi, Sarowati, Kori-kori, Bebele,

Telp: +6285664736234

Email: eshalimi@yahoo.com and in the Papua island, the plant was called as Dogaukue, Gogaukue, and Sandanan (Januati \& Yusron, 2005; Winarto \& Surbakti, 2002; Syukur \& Harnani, 2001; Muhlishah, 2002; Hargiono, 1995). Bunyaprapharsara et al., (1999), listed the name of the plant in other part of the worlds. In Europe, the plant was called as Pennywort (England), Cotyliole (France), Wassernabel (Germany), and Padarvoet (Holland). In India the plant was called as Barahmi, Karinga and Barhamamanduki. In Thailand the plant was called as Buak Bok and in the Phillipine it was called as Yahongyahong. Furthermore, Steenis (1977), described the scientific classification of the plant as follows:

Kingdom : Plantae

Division : Spermatophyta

Sub-division : Angiospermae

Class : Dicotylodoneae

Order : Umbillales

Family : Umbilliferae

(Apiaceae or Mackinlayaceae)

Genus : Centella

Species : Centella asiatica (L.)

Urban or Hydrocotile asiatica Linn.

The Centella asiatica plant was known as a herbaceous annual plants. The plants mature in about 
three months and the whole plants, including the roots, might be harvested. The plant grows around top soil, with short rhizomes, and long-slender stolone interconnecting one plant to another. The size of the plant, especially, the leaves and stolones as a main component of the yield may be various (Januati \& Yusron, 2005). Many publications listed that the Centella asiatica plant grow in various regions in Indonesia (Januati \& Yusron, 2005; Winarto \& Surbakti, 2002; Syukur \& Harnani, 2001; Muhlishah, 2002; Hargiono, 1995 ), but they did not describe clearly the agronomic traits of the plant in each region. This research, therefore, was intended to describe several agronomic traits that related to yield of the Centella asiatica plant grown at regions with different altitudes.

\section{MATERIAL AND METHOD}

Research method was designed as field survey at several designated area of regions with different altitude followed by descriptive analysis. The area consisted of highland region (>500 $\mathrm{m}$ above sea level); midland region (250-500 $\mathrm{m}$ above sea level) and lowerland region (<250 m above sea level). Consecutively, the regions of the research were Pagar Alam, Lubuk Linggau, and Ogan Ilir, South Sumatera Province. Every region covered three condition sites of dry, swampy (wet), and backyard (Figure 1) in which, five observation plots were established (plot size of $1 \mathrm{~m}^{2}$ ). This research, therefore, consisted of 45 observation plots ( $3 \times 3 \times 5)$. Research observation was done in October to November 2009. The composite soil samples of each observation plot were taken for soil fertility test. Although the samples were taken from different area as outlined above, the soil fertility seemed to be about the same. The samples indicated that the $\mathrm{N} \%$ soil were ranged $5.0-6.5 \%$; the P-Bray ranged from 3.2 to $3.6 \mathrm{ppm}$; the K-dd ranged 3.9-5.0 me/100g soil; and the $\mathrm{pH} \mathrm{H} 2(1: 1)$ ranged 5.1 to 6.0 (Table 1).

The observations on the plants include some agronomic traits of the leaf (shape, size, number of leaf ; and length of the petiole) ; the stolone (the number and the length); the roots (maximum length); and the flower (number of flower per plant). Descriptive analysis was performed on the data by tabulation. Data collection were also enhanced by selected pictures (images) representing the observations.
A

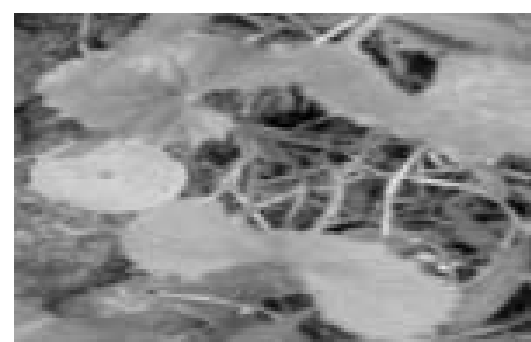

B

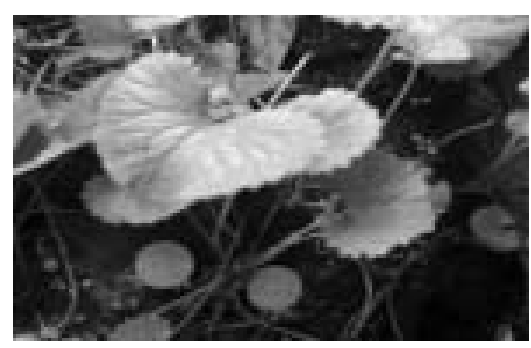

C

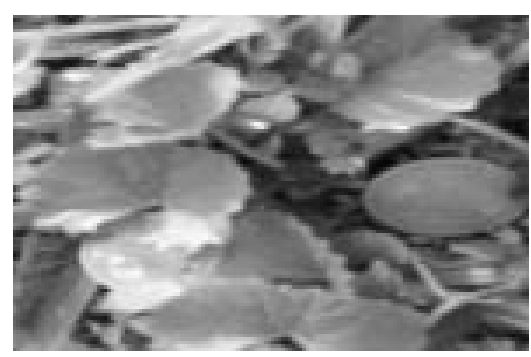

Highland region (>500 $\mathrm{m}$ above sea level)
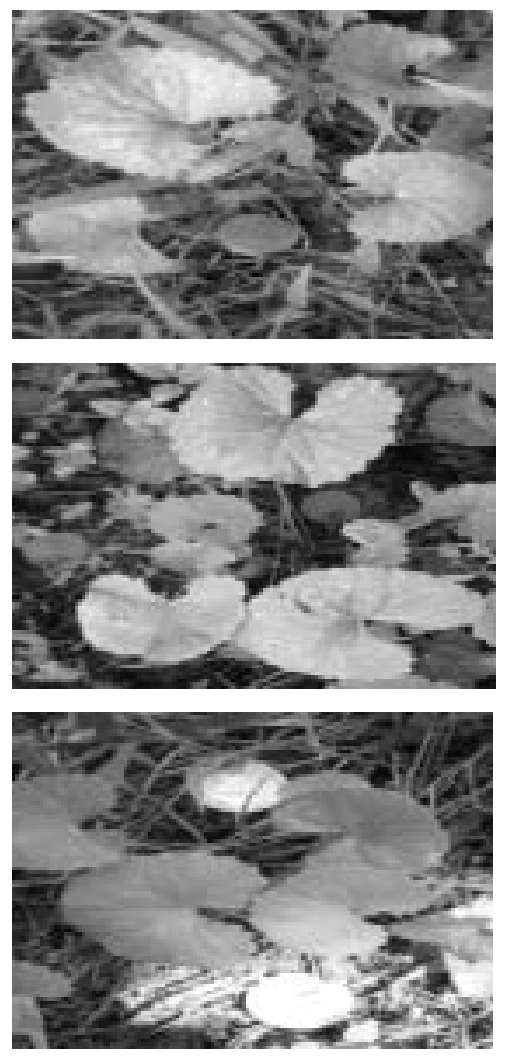

Midland region (250-500 above sea level)
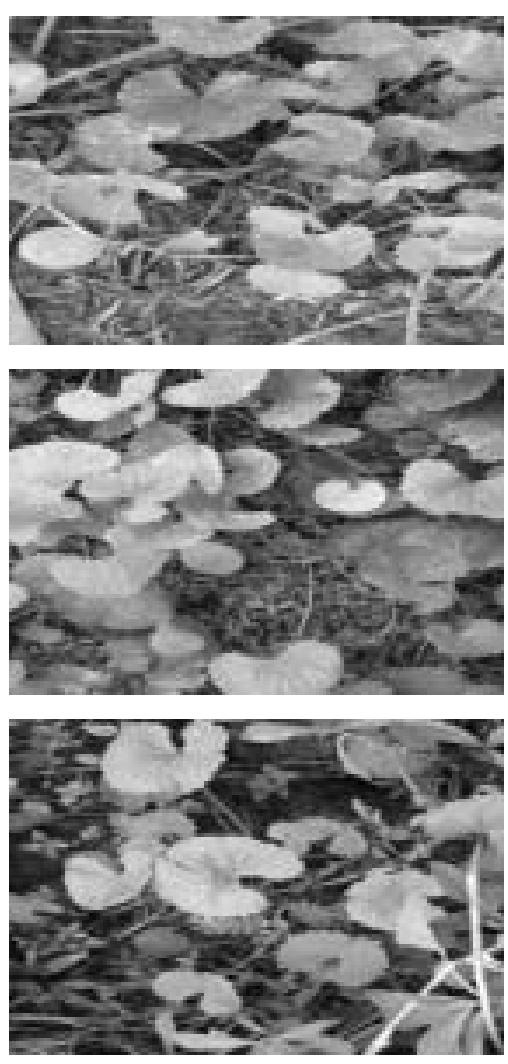

Lowerland region (<250 $\mathrm{m}$ above sea level)

Figure 1. The observation sites of of Centella asiatica plants naturally growns at regions with different altitude (A:Dry; B:Swampywet; C:Backyard) 


\section{RESULTS AND DISCUSSION}

Unlike botanical trait that includes all part of the plant, the agronomic trait includes only certain part of the plant that are directly or indirectly related to yield and cultivation purposes. For the Centella asiatica plant, the agronomic traits include the leaf, the stolone, the root (rhizome), and the flower (Wilson et al., 1972 \& Harjadi, 1996).

In general, this research indicated that, the agronomic traits of Centella asiatica plants grown at regions with different altitudes seemed to be similar.
The leaf of the plants grown at highland region $(>500$ $\mathrm{m}$ above sea level); midland region (250-500 $\mathrm{m}$ above sea level) as well lowland region ( $<250 \mathrm{~m}$ above sea level) appeared to be similar in shape of "kidney like" with un-smooth rounded apices and each individual leaf borne in a single pericladial petioles (Figure 2). The size of the leaves, however, relatively varied as shown on Table 2. There was indication that the leaves of the plants grown at mid and highland regions were larger in size with shorter petiole compared to plants at lower region. This indicated that Centella asiatica plants

Table 1. The soil fertility $(\mathrm{N}, \mathrm{P}, \mathrm{K}$ and $\mathrm{pH})$ of the composite soil samples taken from the observtion sites

\begin{tabular}{|c|c|c|c|c|c|}
\hline \multirow[b]{2}{*}{ Region } & \multirow[b]{2}{*}{ Condition site } & \multicolumn{4}{|c|}{ Soil sample test for } \\
\hline & & $\begin{array}{l}N \\
(\%)\end{array}$ & $\begin{array}{l}\text { P-Bray } \\
\text { ( ppm) }\end{array}$ & $\begin{array}{c}\text { Kdd } \\
\text { (me/100 g) }\end{array}$ & $\begin{array}{c}\mathrm{pH} \mathrm{H} \mathrm{H}_{2} \mathrm{O} \\
(1: 1)\end{array}$ \\
\hline \multirow{2}{*}{$\begin{array}{c}\text { Highland > } \\
500 \text { m above sea level }\end{array}$} & Dryl & 5.5 & 3.5 & 4.4 & 5.4 \\
\hline & $\begin{array}{l}\text { Swampy (wet) } \\
\text { Backyard }\end{array}$ & $\begin{array}{l}5.0 \\
5.5 \\
\end{array}$ & $\begin{array}{l}3.2 \\
3.5 \\
\end{array}$ & $\begin{array}{l}5.2 \\
3.9 \\
\end{array}$ & $\begin{array}{l}5.5 \\
5.2 \\
\end{array}$ \\
\hline \multirow{2}{*}{$\begin{array}{c}\text { Midland > } \\
250 \text { to } 500 \mathrm{~m} \text { above sea level }\end{array}$} & Dryland & 6.5 & 3.5 & 4.2 & 5.9 \\
\hline & $\begin{array}{l}\text { Swampy (wet) } \\
\text { Backyard }\end{array}$ & $\begin{array}{l}6.5 \\
5.0 \\
\end{array}$ & $\begin{array}{l}3.6 \\
3.6 \\
\end{array}$ & $\begin{array}{l}4.2 \\
4.0 \\
\end{array}$ & $\begin{array}{l}5.7 \\
5.1 \\
\end{array}$ \\
\hline \multirow{2}{*}{$\begin{array}{c}\text { Lowerland }< \\
250 \mathrm{~m} \text { above sea level }\end{array}$} & Dryland & 5.6 & 3.5 & 4.5 & 5.5 \\
\hline & $\begin{array}{l}\text { Swampy (wet) } \\
\text { Backyard }\end{array}$ & $\begin{array}{l}5.5 \\
6.5 \\
\end{array}$ & $\begin{array}{l}3.6 \\
3.5 \\
\end{array}$ & $\begin{array}{l}5.0 \\
5.0\end{array}$ & $\begin{array}{l}5.6 \\
6.0 \\
\end{array}$ \\
\hline
\end{tabular}

A
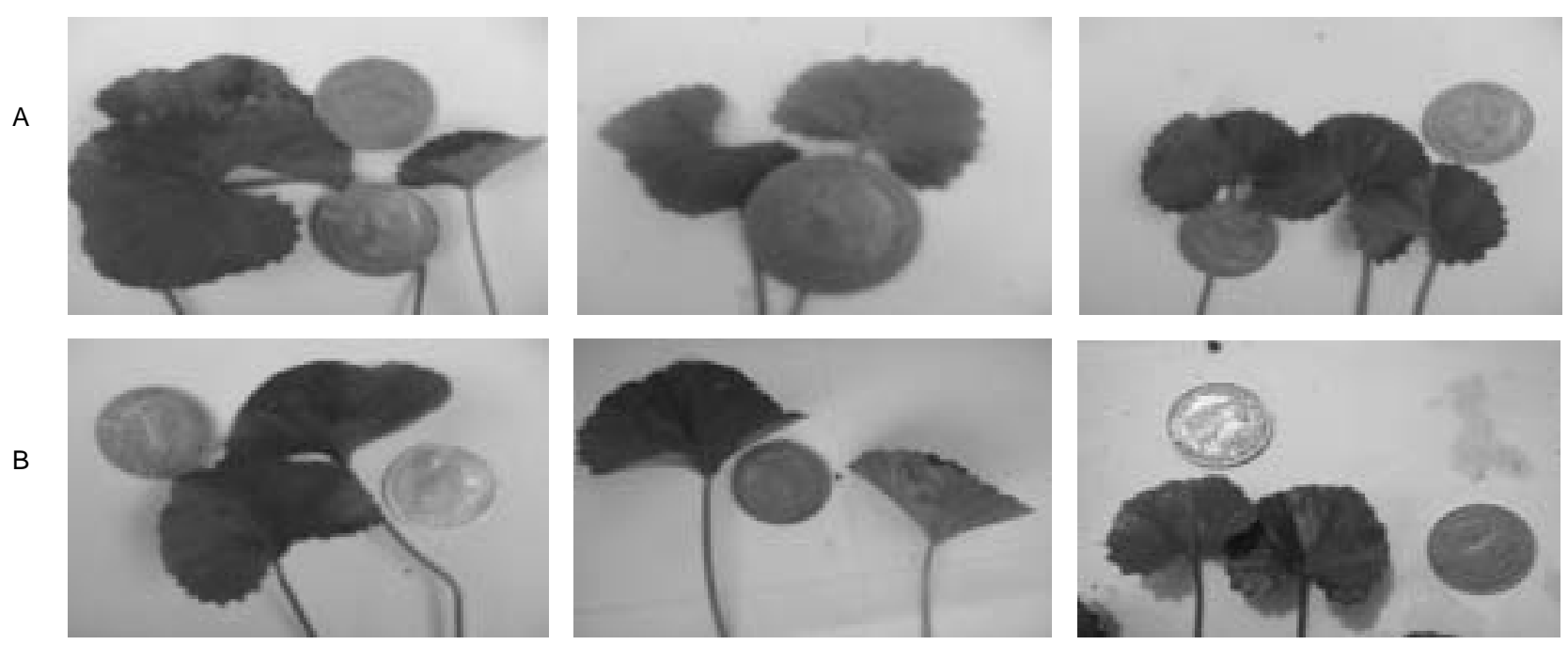

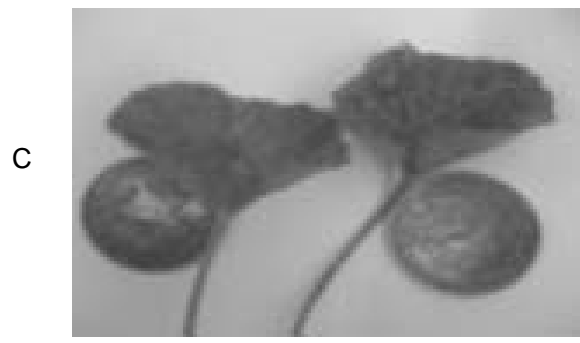

Highland region (>500 $\mathrm{m}$ above sea level)

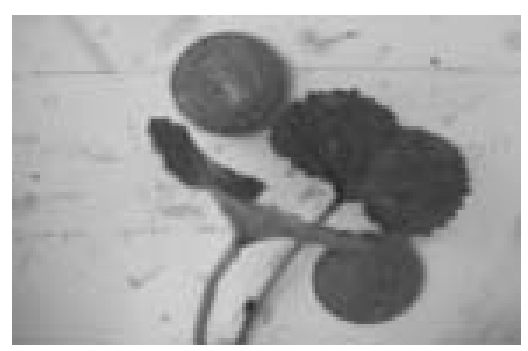

Midland region (250-500 above sea level)

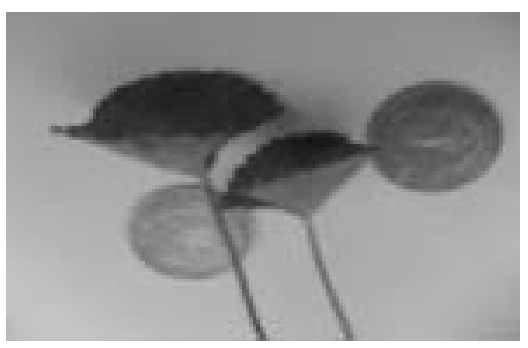

Lowerland region (<250 m above sea level)

Figure 2. The leaves and petiole of Centella asiatica plants naturally growns at regions with different altitude (A:Dry; B:Swampy-wet; C:Backyard) 
grown at midland, and highland were more productive than lowerland plant. The leaf is considered as an important organ of the plant in which the vital metabolism process of photosynthesis occurs (Haryadi, 1996). The shape and number of leaves of the plant were mainly affected by genetics factor, while the size was effected by genetic as well as by non-genetic factors (Gardner, 1972). For Centella asiatica plant, the leaf is very essential as a main component of the plant production (Halimi et al., 1998).

With respect to grow habit of Centella asiatica plants that grow around top soil, the stolones appeared to be the main body of the plant. The stolones basically carry the leaves on the rossets to certain direction of appropriate place to grow. The research indicated that the plants grew at high and midland have more rossets of 8-16 rossets per plant, and more stolone of 5-6 stolones per plant compared to lowerland plants. Unlike the number rosset and stolone per plant, the length of stolone of the plants grown at lower region appeared to be longer than high and midland plant (Table 3). Apparently, the Centella asiatica plants found in lower region were more skinny, longer stolen, with less number of stolone, rosset, and leaves (Figure 1). This appearance coincided with the length of roots, in which, the lowerland plants had a shorter root $(4-7 \mathrm{~cm})$ compared to high and midland plants $(8-15 \mathrm{~cm})$.

The stolones play important role in plant propagation of Centella asiatica, although the seeds might be used for it. The seeds are very small and borne on densely reticulated small fruits of $3-5 \mathrm{~mm}$ (Lasmadiwati et al., 2004; Winarto \& Surbakti, 2002). Research indicated that flowers of Centella asiatica plants naturally grown at highland, midland, and lowland region are similar. The flowers are small (less than 3 $\mathrm{mm}$ ), and hermophrodite, consisted of 2 green brachtea, 6 corolla, 5 stamens, and 2 styles. The flower color could be white, pink or red (Table 4), and born in a small and rounded bunches (umbels), axially erected on the rosset near soil surface. The number of flowers per plant grown in lower region, however, was smaller (18-25 flower per plant), compared to the midland and highland plants of 28-48 flowers per plant (Table 4). This could be indication that Centella asiatica plants grown on midland, and highland were more productive than lowerland plant.

Table 2. The shape and the size of the leaves and length of the petiole of Centella asiatica plants naturally growns at regions with different altitude

\begin{tabular}{|c|c|c|c|c|c|c|}
\hline Region & Condition site & $\begin{array}{l}\text { Leaf } \\
\text { shape }\end{array}$ & $\begin{array}{l}\text { number of } \\
\text { leaves/ } \\
\text { rosset }\end{array}$ & $\begin{array}{l}\text { Leaf } \\
\text { length } \\
(\mathrm{cm})\end{array}$ & $\begin{array}{l}\text { Leafe } \\
\text { width } \\
(\mathrm{cm})\end{array}$ & $\begin{array}{l}\text { Petiole length } \\
\text { (cm) }\end{array}$ \\
\hline \multirow{2}{*}{$\begin{array}{c}\text { Highland > } \\
500 \text { m above sea } \\
\text { level }\end{array}$} & Dry & Kidney & 6 & 3.25 & 4.40 & 7.80 \\
\hline & $\begin{array}{c}\text { Swampy (wet) } \\
\text { Backyard }\end{array}$ & $\begin{array}{l}\text { Kidney } \\
\text { Kidney }\end{array}$ & $\begin{array}{l}4 \\
5 \\
\end{array}$ & $\begin{array}{l}4.15 \\
3.50 \\
\end{array}$ & $\begin{array}{l}5.15 \\
4.90 \\
\end{array}$ & $\begin{array}{l}8.50 \\
8.00 \\
\end{array}$ \\
\hline \multirow{2}{*}{$\begin{array}{c}\text { Midland > } \\
250 \text { to } 500 \mathrm{~m} \\
\text { above sea level }\end{array}$} & Dry & Kidney & 8 & 3.30 & 4.26 & 9.29 \\
\hline & $\begin{array}{c}\text { Swampy (wet) } \\
\text { Backyard }\end{array}$ & $\begin{array}{l}\text { Kidney } \\
\text { Kidney }\end{array}$ & $\begin{array}{l}7 \\
4 \\
\end{array}$ & $\begin{array}{l}3.57 \\
3.36\end{array}$ & $\begin{array}{l}4.26 \\
4.05 \\
\end{array}$ & $\begin{array}{l}8.50 \\
8.71\end{array}$ \\
\hline \multirow{2}{*}{$\begin{array}{c}\text { Lowerland < } \\
250 \text { m above sea } \\
\text { level }\end{array}$} & Dry & Kidney & 5 & 3.15 & 3.01 & 117 \\
\hline & $\begin{array}{l}\text { Swampy (wet) } \\
\text { Backyard }\end{array}$ & $\begin{array}{l}\text { Kidney } \\
\text { Kidney }\end{array}$ & $\begin{array}{l}6 \\
7\end{array}$ & $\begin{array}{l}3.17 \\
3.13\end{array}$ & $\begin{array}{l}3.02 \\
3.04\end{array}$ & $\begin{array}{l}10.2 \\
11.5\end{array}$ \\
\hline
\end{tabular}

Table 3. Number of rosset, number and length of stolone, and length of the root of Centella asiatica plants naturally growns at regions with different altitude

\begin{tabular}{|c|c|c|c|c|c|}
\hline Region & Condition site & $\begin{array}{c}\text { Number of rosset } \\
\text { per plant }\end{array}$ & $\begin{array}{c}\text { Number of stolone } \\
\text { per plant }\end{array}$ & $\begin{array}{c}\text { Maximum length of } \\
\text { stolone }(\mathrm{cm})\end{array}$ & $\begin{array}{c}\text { Maximum length of } \\
\text { root }(\mathrm{cm})\end{array}$ \\
\hline \multirow{2}{*}{$\begin{array}{c}\text { Highland > } \\
500 \text { m above sea } \\
\text { level }\end{array}$} & Dry & 16 & 5 & 62.0 & 12.1 \\
\hline & $\begin{array}{c}\text { Swampy(wet) } \\
\text { Backyard }\end{array}$ & $\begin{array}{l}14 \\
14 \\
\end{array}$ & $\begin{array}{l}6 \\
5 \\
\end{array}$ & $\begin{array}{l}58.0 \\
65.2 \\
\end{array}$ & $\begin{array}{l}11.5 \\
15.1 \\
\end{array}$ \\
\hline \multirow{2}{*}{$\begin{array}{c}\text { Midland > } \\
250 \text { to } 500 \mathrm{~m} \\
\text { above sea level }\end{array}$} & Dry & 10 & 6 & 66.5 & 8.55 \\
\hline & $\begin{array}{c}\text { Swampy (wet) } \\
\text { Backyard }\end{array}$ & $\begin{array}{c}10 \\
8 \\
\end{array}$ & $\begin{array}{l}5 \\
5 \\
\end{array}$ & $\begin{array}{l}62.2 \\
56.7 \\
\end{array}$ & $\begin{array}{l}8.45 \\
11.0 \\
\end{array}$ \\
\hline \multirow{2}{*}{$\begin{array}{c}\text { Lowerland < } \\
250 \text { m above sea } \\
\text { level }\end{array}$} & Dry & 6 & 4 & 67.0 & 5.00 \\
\hline & $\begin{array}{c}\text { Swampy (wet) } \\
\text { Backyard }\end{array}$ & $\begin{array}{l}6 \\
6 \\
\end{array}$ & $\begin{array}{l}3 \\
3\end{array}$ & $\begin{array}{l}67.0 \\
97.0\end{array}$ & $\begin{array}{l}7.00 \\
4.15\end{array}$ \\
\hline
\end{tabular}


Table 4. Number of flowers of Centella asiatica plants naturally growns at regions with different altitude

\begin{tabular}{|c|c|c|c|}
\hline Region & Condition site & Number flower per plant & $\begin{array}{c}\text { Flower color } \\
\text { observed }\end{array}$ \\
\hline \multirow{3}{*}{$\begin{array}{c}\text { Highland > } \\
500 \text { m above sea level }\end{array}$} & Dry & 40 & white, pink, red \\
\hline & Swampy (wet) & 47 & white, pink, red \\
\hline & Backyard & 40 & white, pink, red \\
\hline \multirow{3}{*}{$\begin{array}{c}\text { Midland > } \\
250 \text { to } 500 \mathrm{~m} \text { above sea level }\end{array}$} & Dry & 35 & white, pink, red \\
\hline & Swampy (wet) & 48 & white, pink, red \\
\hline & Backyard & 38 & white, pink, red \\
\hline \multirow{3}{*}{$\begin{array}{c}\text { Lowerland < } \\
250 \text { m above sea level }\end{array}$} & Dry & 21 & white, pink, red \\
\hline & Swampy (wet) & 18 & white, pink, red \\
\hline & Backyard & 25 & white, pink, red \\
\hline
\end{tabular}

\section{CONLUSSION}

The agronomic traits of Centella asiatica plants were about the same for general appearance of leaf shape and flower color. The leaf size, number and length of stolone, number of rossets, length of rhizomes, and number of flowers, however, were varied depending on the region.

The Centella asiatica plants grown at highland and midland region tend to have larger leaf size, shorter petiole, more number of rossets and stolone, longer rhizomes, shorter stolone, and more flowers per plant compared to the plants of lowerland region. This could be indication that Centella asiatica plants grown on midland, and highland were more productive than lowerland plant. The high and midland regions with altitude of $>250 \mathrm{~mm}$ above sea level appeared to be appropriate area for production of Centella asiatica.

\section{AKNOWLEDGEMENT}

Sincere appreciation is given to Stepanus Ginting for his help in field observations for this research.

\section{REFERRENCES}

Brinkhause, B. \& Lindner, M. 2000. Chemical, pharmacological and clinical profile of the East Asian Medical Plant of Centella asiatica. Phytomedicine 7(5): 427-48.
Bunyaprapharsara, LS de Padua \& Lemmens, R.H.M.J. 1999. Plant resources of South-East Asia. Bogor: Porsea Publication.

Dalimata, S. 2000. List of Medical Plants of Indonesia (translated title). Jakarta: Trubus Agrowidia.

Gardner, E.J. 1972. Principle of genetics 4th ed. New York: John Wiley and Son Inc.

Halimi, E.S., Djafar, Z.R. \& Kamaludin, H.H. 1998. Use of medical plants as component for traditional medication at South Sumatera (translated title). J. Tanaman Tropika I(2): 59-66.

Hargono, P. 1995. Use of medicine plants for home medication (translated title). Jakarta Rineka.

Harjadi, M.M.S. 1996. Introduction to agronomy (translated title). Jakarta : Gramedia Pustaka Utama.

Januati, M. \& Yusron, M. 2005. Cultivation technology of Centella asiatiaca plant (translated title). Bogor: Reserach Institute for medicine and aromatic plants.

Khare, C.P. 2003. Indian herbal remedies: Rational western therapy, ayurvedic, and other traditional usage. New Delhi: Springer Pub. Co.

Lasmadiwati, E., Herminati, M.M. \& Indriani, Y.H. 2004. Pegagan. Jakarta: Penebar Swadaya.

Muhlisah, F. 2002. Home medicine plants (translated title). Jakarta: Penebar Swadaya.

Sangat, H., Ervijal, M., Zuhud, A.M. \& Damayanti, E.K. 2000. Dictionary of disease and medicine plants of Indonesia (translated title). Jakarta: Pustaka Populer.

Steenis, C.G.G.J.V. 1997. Flora. Jakarta: Pradya Pamita.

Syukur, C. \& Harnani. 2001. The culivation technology of medicine plants for commercial purpuse (translated title). Jakarta: Penebar Swadaya.

Wilson, C.L., Loomis, W.E. \& Croadsdale, H.T. 1972. Botany 3 rd ed. New York: Holt Rinehart and Son.

Winarto, W.P. \& Surbakti, M. 2002. Virtousity and usage of Centella asiatica plants (translated title). Jakarta: Agromedia Pustaka. 